\title{
Respon Nahdlatul Ulama terhadap Gempuran Aliran Fundamental; Telaah Kritis Radikalisme Intoleran dan Pudarnya Moderatisme Islam
}

\author{
Maskuri Bakri \\ Universitas Islam Malang, Indonesia \\ masykuril@unisma.ac.id
}

\begin{abstract}
The purpose of this study is to describe and anlyse the identity of Islamic nonmainstream, the existence of educated middle class of Nahdatula Ulama (NU), political practice problem, Nahdatul Ulama; universalism and moderatism of Islamic teaching, as well as NU within the tradition of global society. This study used inductive-deductive approach method with content analysis. From the result of analysis, Islam that is displayed by mainstream groups is now getting great onslaguht from non-mainstream from transnational circles with diverse faces, this second group is more violent and has a more structured and massive regeneration system and tends to dominate strategic institutions in Indonesia, with a fiercer appearance and openly even carrying the caliphate system in government, and trying to enter the national political arena as a strategic vehicle. On the other hand, the mainstream group began to feel and received strong pressure from the non-mainstream so that it began to step aside, even though it had long colored the nation and state of Indonesia, the other side of the non-mainstream group began to take center stage. However, it turns out that there is still hope that educated mainstream groups will begin to show their potential even though they have not been properly consolidated in facing non-mainstream groups. Islam that is displayed by mainstream groups has actually got a place from many circles in this world, because their life always adheres to the principles of tolerant, moderate, harmony, proportional, and amar ma'ruf nahi munkar consistently, even in the global era it can also adapt to the life of time.
\end{abstract}

Keywords: Aswaja, onslaught, fundamentals, intolerant radicalism, moderatism

\begin{abstract}
Abstrak
Tujuan kajian ini untuk mendeskripsikan dan menganalisis tentang identitas Islam non mainstream, eksistensi kelas menengah terdidik Nahdatul Ulama (NU), problem politik praktis, NU; universalisme ajaran dan moderatisme Islam, serta NU di tengah tradisi masyarakat global. Sedangkan metode kajian mengunakan pendekatan induktifdeduktif dengan conten analisis. Dari hasil kajian bahwa Islam yang ditampilkan oleh kelompok mainstream kini mendapatkan gempuran hebat dari non mainstream dari kalangan transnasional dengan wajah yang beragam, kelompok kedua ini lebih keras dan memiliki sistem kaderisasi lebih terstruktur dan massif serta cendrung menguasai terhadap lembaga-lembaga strategis di Indonesia, dengan tampilan yang lebih garang dan terang-terangan, bahkan mengusung sistem khilafah dalam pemerintahan, dan berusaha masuk pada gelanggang politik nasional sebagai kendaraan strategisnya. Sisi lain, kelompok mainstream mulai terasa dan mendapatkan desakan keras dari non mainstream sehingga mulai menepi, walaupun telah lama mewarnai bangsa dan negara Indonesia, sisi lain kelompok non mainstream mulai mengetengah. Namun demikian, ternyata masih ada harapan kaum terdidik kelompok mainstream mulai menunjukkan potensinya walaupun belum terkonsolidasikan dengan baik dalam menghadapi kelompok non mainstream. Islam yang ditampilkan oleh kelompok mainstream sesungguhnya telah mendapat tempat dari banyak kalangan di dunia ini, karena kehidupannya selalu berpegang pada prinsip toleran, moderat, harmoni, proporsional,
\end{abstract}

Tribakti: Jurnal Pemikiran Keislaman

Volume 32, Nomor 1, Januari 2021 
dan amar ma'ruf nahi munkar secara istiqomah, bahkan dalam era global juga dapat beradaptasi dengan kehidupan zaman.

Kata Kunci: Aswaja, Aliran fundamental, radikalisme intoleran, moderatisme

\section{Pendahuluan}

Bapak Bangsa KH Abdrrahman Wahid di masa hidupnya jauh hari telah meramalkan kemungkinan besar terjadi pergesaran dominasi umat Islam mainstream ke aliran lain yang non mainstream, ditandai dengan semakin ketengahnya umat Islam radikal intoleran atau Islam non mainstream di ruang publik negara-bangsa. Sementara, Islam mainstream atau Islam moderat lambat laun mulai tergusur dan bergerak ke kawasan pinggiran dan tidak lagi mendominasi. Dalam pernyataan Gus Dur secara tegas mengungkapkan bahwa belakangan ini suara dari kelompok Islam garis keras tampak mendominasi wacana politik, bahkan terang-terangan padahal jumlah pengikutnya tidaklah banyak dibanding pengikut Islam moderat. ${ }^{1}$ Oleh karena itu, merupakan tantangan bagi umat Islam moderat untuk menyusun strategi yang taktis dan mengambil kembali inisiatif untuk menjadi yang terdepan dalam membawa Islam toleran, moderat, harmoni dengan genggaman yang kuat dan tetap humanis, santun bermoral dengan dasar nilai-nilai Islam rahmatanlil'alamien.

Gus Dur juga sempat menyoroti kebangkitan umat Islam radikal intoleran dengan berbagai varian di tanah air. Secara gamblang Gus Dur mempredeksi ke wacana publik tentang Islam di Indonesia akan didominasi oleh kelompok Laskar Jihad, Majlis Mujahidin, Syi'ah, Front Pembela Islam, Hiszbut Tahrir Indonesia walau sudah dibubarkan tetapi pengikutnya masih melakukan operasi hingga saat ini. Pada saat yang sama, Islam mainstream semakin kehilangan peran-peran pentingnya di ranah kebangsaan, karena militansi kelompok-kelompok non mainstream masuk ke ranah institusi pendidikan mulai dari tingkat sekolah dasar, menengah, mapun perguruan tinggi. ${ }^{2}$

Boleh dipredeksi, bahwa wajah gerakan Islam di Indonesia dikemudian hari tidak lagi didominasi kelompok yang selama ini menjadi mainstream utama, seperti NU, Muhammadiyah, dan beberapa kelompok besar seperti Ikatan Cendekiawan Muslim Indonesia dan lainnya. Namun, gerakan Islam Indonesia akan banyak diwarnai kelompok non mainstream yang akhirakhir ini telah melakukan gerakan-gerakan 212, dengan mobilisasi masa besar-besaran dan banyak mengganggu aktifitas masyarakat di jalan, bahkan banyak menyulitkan aparat keamanan dan pemerintah. Mereka akan banyak mewarnai dengan segala variannya dan gerakan-gerakan yang menjadi wataknya. Misalnya Laskar Jihad, Front Pembela Islam, Majlis Mujahidin, Hizbut Tahrir dengan sikap radikal intolerannya, kadang juga lembut. Gejala bangkitnya Islam non

\footnotetext{
${ }^{1}$ Zuhairi Misrawi, Hadratussyaikh Hasyim Asy'ari: moderasi, keumatan, dan kebangsaan (Penerbit Buku Kompas, 2010), 107.

${ }^{2}$ Badrun Alarna, NU, Kritisisme dan Pergeseran Makna Aswaja (Yogyakarta: Tiara Wacana, 2000), 77. 
mainstream bisa dilihat pada awal-awal era reformasi, setelah bertahun-tahun tidak mempunyai saluran untuk bicara, mereka menunjukkan kekuatannya untuk bicara, meski dengan susah payah, dan kekuatannya didukung kemampuannya untuk memanfaatkan saluran komunikasi diberbagai institusi BUMN, BUMS, partai politik, lembaga-lembaga pendidikan dan lain sebagainya. ${ }^{3}$

Bila diperhatikan secara seksama, pernyataan Gus Dur dalam perkembangannya bukanlah hanya sebatas isapan jempol dan sekedar berbicara belaka. Ketika, diskursus tentang Islam Indonesia benar-benar didominasi beragam warna paham umat Islam yang dengan sengaja diusung oleh kelompok non mainstream, tidak berlebihan, jika dinyatakan wacana publik kebangsaan di dominasi terorisme Islam dengan berbagai varian manifestnya, umat Islam non mainstream menuntut penutupan gereja, sweping gerakan anti maksiat di berbagai kota pada bulan ramadhan, konstitusionalisme Islam atau khilafah, perda syari'ah, dan begitu seterusnya. ${ }^{4}$

Islam non mainstream, menjadi entitas baru yang mewarnai peta Islam di Indonesia, bahkan menjadi corak baru yang tidak lagi operasi senyap tetapi justru menunjukkan wajah baru yang terang-terangan dan berani. Oleh karenanya, menurut Greetz, Islam tidak lagi hanya direpresentasikan oleh santri, priyayi, dan abangan. Peta Islam Indonesia juga bukan lagi hanya menampakkan beragam kantong yang menampilkan watak dasar moderat. Kantong-kantong yang mengadhiluhungkan toleransi dan lokalitas. ${ }^{5}$ Sebaiknya, peta Islam Indonesia saat ini memiliki cukup banyak varian atau kental dengan berbagai ragam corak dan visinya.

Islam moderat - yang disebut-sebut sebagai Islam mainstream, dalam derajat tertentu masih cukup survival dan menjadi bagian penting dari peta Islam Indonesia. Beberapa dapat disebut, misalnya, Nahdlatul Ulama, Muhammadiyah, Al-Washliyah, Mathla'ul Anwar, Nahdlatul Wathan dan seterusnya. ${ }^{6}$ Di saat yang sama, gerakan Islam baru yang berwajah transnasional juga turut mewarnai. Sebut saja mislanya, Jama'ah Tabligh Indonesia (JTI), Jama'ah Ahmadiyah Indonesia (JAI), Majelis Mujahidin Indonesia (MMI), Fron Pembela Islam (konon berafilisai pada Nahdlatul Ulama', tetapi tampilannya cukup keras) dan masih banyak

\footnotetext{
${ }^{3}$ Proceeding International Seminar on Islamic Civilization, Developing Role of Islamic Education on Multicultural Life and Religious De-Radicalization, (Post Graduate Program Qur'anic Sciences University Central Java in Wonosobo in Cooperation with Agency, Development, Education and Training (Balitbang Diklat) Ministry of Religious Affairs Republic of Indonesia, 2019), 77.

${ }^{4}$ Maskuri Bakri, Radikalisme dan Intoleran dalam Perspektif Bhinneka Tunggal Ika (Malang: Lembaga Penelitian dan Pengabdian pada Masyarakat Universitas Islam Malang, 2020), 66.

${ }^{5}$ Sahilun A. Nasir, Pemikiran Kalam (Teologi Islam): sejarah, ajaran, dan perkembangannya (Jakarta: Rajawali Press, 2010), 190.

${ }^{6}$ Misrawi, Hadratussyaikh Hasyim Asy'ari; moderasi, keumatan, dan kebangsaan. (Penerbit Buku Kompas, 2010), 87.
}

Tribakti: Jurnal Pemikiran Keislaman

Volume 32, Nomor 1, Januari 2021 
lagi. Mereka yang disebut belakangan, seringkali diidentifikasi dengan Nahdlatul Ulama sebagai bagian utama dari Islam non mainstream. ${ }^{7}$

Masing-masing dari dua kutub itu, dengan derajat berbeda, cukup ekspansif, terlebih mereka yang masih dalam kutub non mainstream. Perbedaan cara pandang, pengalaman religiousitas dan bahkan respon atas politik kebangsaan begitu kental mewarnai kedua kutub Islam Indonesia, selama ekspansi diberlakukan oleh masing-masing kutub Islam tersebut. Tak urung, gesekan-gesekan dan bahkan konflik dalam skala kecil terjadi, antara Islam non mainstream. Tidak hanya itu, konflik dalam skala mainstream begitu ekstensi dan ekspansif. Sementara Islamisasi dipahami kutub Islam mainstream sebagai bagian dari penggerusan terhadap umat yang sebelumnya berada di dalam otoritas mereka. ${ }^{8}$

Pengamatan sementara bahwa kelompok-kelompok non mainstream yang disebutkan di atas telah berkembang di berbagai pedesaan, misalnya Pandaan Raya yang beralamatkan di Jalan Gang Gangsir Ngampes Nogosari Pandaan. Dan tentunya, sangat tidak sulit untuk menemukan alamat tersebut. Tidak hanya itu, kawasan sekitar sudah mulai dapat ditemukan, baik anggota maupun lembaga Islam non mainstream, seperti Prigen, Bangil, Gempol, dan seterusnya. Hal yang sama juga ditemukan di berbagai daerah di Jawa Timur. Dalam suatu acarah halaqah tentang Khittah Nahdliyah yang diselenggarakan oleh Pengurus Wilayah Nahdlatul Ulama (PWNU) Jawa Timur beberapa waktu lalu, sempat terekam laporan di berbagai Pengurus Cabang Nahdlatul Ulama (PCNU) se Jawa Timur berbagai kasus ekspansi kelompok-kelompok non mainstream ke kantong-kantong warga NU. Bentuk ekspansi ini sangat beragam, mulai dari berdialog menawarkan konsep doktrin, mengajak, bahkan hingga sudah mulai secara terang-terangan melarang dan mengharamkan tradisi Ziarah Kubur, Tahlilan, berjanjen, diba 'iyah dan seterusnya. Kampanye dan rekrutmen anggota cukup intensif oleh Islam non mainstream. Sangat mudah, misalnya, mendapatkan akses buletin Al-Islam. Beberapa masjid di Pandaan termasuk masjid AnNur Petungasri, Cheng Ho Kasri, Ar-Rahmah Sukun Sumber Gedang, dan begitu seterusnya, selalu mendapatkan buletin Al-Islam setiap Jum'at untuk para jama'ah secara cuma-Cuma. ${ }^{9}$

Dalam skala nasional, popularitas kelompok-kelompok non mainstream cukup luar biasa. Pertemuan akbar di Jakarta dapat dijadikan sebagai salah satu indikator utama. Pertemuan yang bertajuk "Konferensi Khilafah Internasional 2007” dihadiri oleh 80.000 (delapan puluh ribu) orang, pertemuan 212 yang memenuhi jalan-jalan di Jakarta di 2019, Isu utamanya terkait politik nasional dan menolak demokrasi ala mainstream, bahkan secara terbuka sekarang representasinya adalah Partai Keadilan Sejahtera (PKS) sebagai rumah besar politiknya.

\footnotetext{
${ }^{7}$ Proceedings Islamic International Conference (IIC). The Elements of Multicultural Curriculum in Aspect of Evaluating Curriculum; The Concepts, Nature, and Evaluation Models (Malang: Post Graduate Islamic University of Islam Malang, 2018), 88

${ }^{8}$ Abdul Qodir Ridwan, Gerbang Pesantren, Pengantar Memahami Ajaan Ahlussunnah wal Jama'ah (Kediri: Litbang Lembaga Ittihadul Muballigin PP. Lirboyo, 2010).

${ }^{9}$ Muhyiddin Abdusshomad, Hujjah NU (Surabaya: Khalista, 2008), 63.
} 
Lalu, bagaimana dengan masa depan Islam mainstream atau Islam moderat di tanah air, khususnya Nahdlatul Ulama? Saat ini, terlalu dini membuat konklusi walaupun sinyal-sinyal sudah mulai terlihat, Islam mainstream hanya akan menjadi kenangan yang pernah hadir dalam sejarah Islam Indonesia, bila tidak terkonsolidasi dan diantisipasi. Namun, pada masa yang cukup jauh kedepan, konklusi sementara di atas sangat terbuka berkemungkinan menjadi kenyataan. Bila ditarik pada ranah yang lebih spesifik, keberadaan NU yang telah begitu kenyang dengan pengalaman akan menjadi bagian dari sejarah Islam Indonesia, yang hanya tinggal kenangan bila tidak di pahami oleh seluruh warga NU. Cukup penting dicatat bahwa, sebagian besar muslim di tanah air yang beralih menjadi kelompok non mainstream dari kalangan nahdliyyin. Gerusan yang begitu kuat tak urung berakibat semakin banyaknya anggota NU yang eksodus menjadi Majlis Mujahidin Indonesia, Fron Pembela Islam, dan seterusnya. Semakin intensifnya Islam non mainstream merebut modal sosial NU paling utama - pesantren dan masjid, juga dapat dipahami menjadi salah satu driving force semakin menipisnya kekuatan NU. ${ }^{10}$ Sementara, upaya-upaya serius untuk mengantisipasi fenomena eksodus, belum sepenuhnya dilakukan oleh NU diseluruh level struktur kelembagaan yang dimiliki.

\section{Metode}

Pendekatan yang digunakan adalah library research, bersumber dari buku-buku yang berkenaan dengan ke-NU-an, aliran fundamental, radikalisme intoleran, dan moderatisme Islam serta buku-buku lain yang memiliki keterkaitan dengan tema penelitian. Selain bersifat kepustakaan, penelitian ini bersifat kualitatif, karena data yang dihasilkan adalah bersifat deskriptif analitis, yakni memaparkan permasalahan secara apa adanya berdasarkan sumbersumber rujukan otoritatif dalam bidang sosiologi agama, antrologogi budaya, dan sosial politik. Penelitian kaulitatif adalah penelitian yang digunakan untuk mendeskripsikan dan menganalisis fenomena, peristiwa, aktivitas sosial, sikap, kepercayaan, perpepsi orang secara individual maupun kelompok. ${ }^{11}$

Teknik pengumpulan data dengan memanfaatkan sumber pustaka atau bahan-bahan koleksi perpustakaan, dengan cara membaca teks buku, jurnal penelitian terdahulu, literaturliteratur, media pemberitaan baik online maupun cetak yang sesuai dengan topik yang dibahas dalam kajian ini, agar data yang diperoleh benar-benar memiliki landasan teori dan acuan yang jelas dan pendalamannya digunakan teknik focus group discutiaon.

\footnotetext{
${ }^{10}$ Misrawi, Hadratussyaikh Hasyim Asy'ari, moderasi, keumatan, dan kebangsaan. (Penerbit Buku Kompas, 2010), 107.

${ }^{11}$ Maskuri Bakri, Metode Penelitian Kualitatif; Teori dan Praktek (Jakarta: Nirmana Press, 2014), 77.
} 
Setelah semua data terkumpul, langkah selanjutnya yaitu pengolahan data, yang kemudian data itu di analisis dengan menggunakan analisis konten (content analiysis), untuk menarik kesimpulan melalui usaha menemukan karakteristik pesan, dan dilakukan secara obyektif dan sistematis, ${ }^{12}$ sehingga mendapatkan gambaran tentang identitas Islam non mainstream, eksistensi kelas menengah terdidik Nahdatul Ulama (NU), problem politik praktis, NU; universalisme ajaran dan moderatisme Islam, serta NU di tengah tradisi masyarakat global.

\section{Hasil dan Pembahasan}

\section{Identitas Islam Non Mainstream}

Dikalangan akademisi, identitas Islam non mainstream memiliki narasi sangat beragam. Martin misalnya, mengajukan terma "sempalan" untuk menggantikan non mainstream. ${ }^{13}$ Dalam konteks Islam Indonesia, sempalan mengandaikan varian baru gerakan Islam yang menyimpang atau memisahkan diri dari ortodoksi dan aliran induk. Istilah ini juga menunjuk pada entitas yang relatif, konsep yang dinamis, tidak mutlak dan abadi. Artinya, bisa jadi pada tahapan tertentu gerakan Islam sempalan dapat bergeser menjadi ortodoksi atau Islam mainstream, dan pada saat yang sama, ortodoksi menjelma kedalam bentuk Islam sempalan.

Identitas berbeda terhadap Islam non mainstream, yakni Islam Indonesia pasca jatuhnya Suharto mengalami dinamika yang menarik, baik dari aspek pemain (agency) maupun ideologi. ${ }^{14}$ Dari perspektif agency, pergerakan Islam di Indonesia di babakan waktu yang dikenal dengan era reformasi ini tidak lagi didominasi oleh pemain kasar yang selama ini mengemuka, seperti direpresentasikan oleh Nahdlatul Ulama (NU) dan Muhammadiyah sebagai dua organisasi massa Islam arus utama (mainstream), akan tetapi juga diramaikan oleh aktivis kelompok-kelompok baru. Kelompok Islam yang disebut terakhir ini, meski bisa dikatagorikan sebagai kelompok pinggiran (peripheral) karena jumlah pengikutnya yang tidak sebesar NU dan Muhammadiyah, mewarnai pergerakan sosial politik di Indonesia akibat artikulasi ideologinya di ruang publik yang ekspresif dan cenderung masif. ${ }^{15}$

Pada hakekatnya, akar-akar kelompok Islam non-mainstream ini telah ditemukan dalam sejarah bangsa Indonesia, mulai abad ke-18 hingga awal-awal kemerdekaan yang menjelma dalam bentuk gerakan-gerakan sempalan yang tidak setuju dengan Negara Kesatuan Republik Indonesia (NKRI). Bentuk-bentuknya dapat ditelusuri mulai dari gerakan sempalan, baik secara

\footnotetext{
${ }^{12}$ Lexy J. Moleong, Metode Penelitian Kualitatif (Jakarta: Grafindo, 2002), 163.

${ }^{13}$ Hasan, Tholhah dkk, Radikalisme dalam Persepktif Budaya (Jakarta; Lantabora, 2017), 66.

14 Maskuri Bakri, Radikalisme dan Intoleran dalam Perspektif Bhinneka Tunggal Ika (Malang: Lembaga Penelitian dan Pengabdian pada Masyarakat Universitas Islam Malang, 2020), 44.

15 Faisal Ismail, NU, Moderatisme, dan Pluralisme: Konstelasi Dinamis Keagamaan, Kemasyarakatan, dan Kebangsaan (IRCISOD, 2020). 48. 
terang-terangan dalam bentuk pemberontakan maupun yang lebih halus dalam bentuk penyebaran ide dan konsolidasi internal antar anggota dan kader-seperti; DI/TII, Masyumi, DDII, dan lainnya secara massif membuat gerakan yang dimulai dari usroh-usroh di kampus-kampus. ${ }^{16}$ Dari sinilah akhirnya hadir organisasi semacam Tarbiyah (organisasi keagamaan yang membidani lahirnya Partai Keadilan (PK) atau Partai Keadilan Sejahtera/PKS), Majelis Mujahidin Indonesia (MMI), Jamaah Islamiyah (JI) dan seterusnya.

Logosentrisme gerakan Islam non-mainstream ini semakin terang-terangan semenjak fase reformasi mulai digulirkan. Jika pada era Orde Baru, berbagai gerakan Islam sempalan benarbenar dibatasi ruang geraknya, namun memasuki era reformasi, seirama dengan tuntutan demokratisasi, gerakan Islam non-mainstream secara terbuka mulai berebut wacana keagamaan, sosial, politik, bahkan kebudayaan di ruang publik. Tarbiyah, sebagai Ormas keagamaan tak ubahnya yang dalam banyak kasus mengidealkan Ihwanul Muslimin (IM) sebagai modal gerakan dengan segera akhirnya membidani berdirinya Partai Keadailan (PK) yang saat ini berganti nama dengan Partai Keadilan Sejahtera (PKS). Hingar-bingar Tarbiyah ini lambat laun diikuti oleh Ormas keagamaan yang sevisi semisal; Majelis Mujahidin Indonesia MM), Jama'ah Tabligh, Jama'ah Islamiyah (JI) dan Front Pembela Islam (FPI). Untuk kasus keempat gerakan Islam radikal ini dapat dipahami sebagai metamorfosis atau juga bisa dianggap sebagai pecahan dari gerakan salafi sebelumnya yang dipelopori oleh Abdullah Sungkar.

Secara sederhana, untuk membedakan indentitas Islam non-maintream dengan Islam mainstream (terutama NU maupun Muhammadiyah yang misi utamanya adalah Islam Ahlusunnah wa al-Jama'ah) dapat dicirikan dalam beberapa hal mendasar; Pertama, ideologi Islam non-maintream secara nyata-nyata mengapdosi nilai-nilai ajaran dari sumber aslinya (di Timur Tengah) secara apa adanya, alias ghoiru qobilin li an-Niqos wa ghoiru qobilin li alTaghyir, tanpa disesuaikan dengan dinamika sosial-politik dan budaya di mana ajaran tersebut disebarkan di tempat atau negara tujuan. Kedua, mengadopsi sistem religi dengan apa adanya tersebut, konsekuensinya adalah menolak-bahkan mengharamkan-segala bentuk budaya maupun tradisi lokal. Ketiga, menolak ideologi barat seperti faham demokrasi, sekularisme dan liberalisme. Keempat, sebagai ganti dari resistensi (penolakan) terhadap ideologi barat, Islam non-mainstream menawarkan konsep Islam sebagai satu-satunya ideologi final dalam mengatur kekuasaan politik negara. Tidak mengherankan jika agenda besar Islam non-manstream ini adalah mengusung isu syari'ah Islam, Negara Islam atau khilafah Islamiyah. Kelima, sebagai akibat langsung maupun tidak langsung benturan dengan pihak penguasa di berbagai negara, model perjuangan yang ditempuh oleh kelompok Islam non-maistream banyak melibatkan kontak fisik, alias dengan cara-cara kekerasan. ${ }^{17}$

${ }^{16}$ Endang Supriadi, Ghufron Ajib, Sugiarso, Intoleransi dan Radikalisme Agama; Konstruk LSM tentang Program Deradikalisasi (Semarang: JSW/Jurnal Sosiologi Walisongo Vol 4, No 1, 2020), 67.

${ }^{17}$ Alarna, NU, Kritisisme dan Pergeseran Makna Aswaja.

Tribakti: Jurnal Pemikiran Keislaman

Volume 32, Nomor 1, Januari 2021 
Masyarakat Islam, telah mengakui bahwa Ahlussunah wa al Jama'ah sebagai faham, aliran atau ideologi dari berbagai gerakan, kelompok dan organisasi yang ada di Indonesia. Oraganisasi yang paling terkenal secara riil ideologis-konstitusional yang meyakini dan mengakui serta membela Aswaja adalah Nahdlatul Ulama. Sedangkan Muhammadiyah secara implisit telah mengakui dan mengikuti ideologi Áswaja, terlihat dari salah satu keputusan Majlis Tarjih menyatakan bahwa keputusan tentang keimanan adalah aqidah Ahlul Haq Wassunnah, seorang puritanis. ${ }^{18}$

Kalangan Tarbiyah merumuskan bahwa Aswaja tidak jauh berbeda dengan organisasi NU, dengan rumusan yang lebih ketat, karena cenderung "menyesatkan" pengikut Ibnu Taimiyyah dan Wahabi. Sedangkan rumusan Aswaja Miftakhul Anwar pada hakikatnya tidak berbeda dengan NU, namun gerakan ini dapat menampung pengikut Ibnu Taimiyah dan Wahabi ke dalam Aswaja. Pembahasan dan wacana intelektual di atas, menunjukkan betapa Aswaja mendapat perhatian dari berbagai kalangan, sebagai satu-satunya aliran yang benar dan aman dalam Islam (al-firqah al-najiyah), dan Aswaja telah dipahami dalam berbagai pengertian oleh berbagai kelompok dan gerakan Islam, dengan pandangan yang berbeda, hal ini harus selalu diwaspadai, karena Islam itu lembut, toleran, moderat dan harmonis, ${ }^{19}$ dan juga dari mana membaca dan memahaminya, sehingga perlu kewaspadaan terhadap berbagai gerakan yang ada di masyarakat.

\section{Eksistensi Kelas Menengah Terdidik NU}

Kekhawatiran atas maraknya propaganda kelompok Islam radikal intoleran (Islam nonmainstream) akan berujung pada pudarnya nilai-nilai aswaja di kalangan masyarakat grass-root NU yang telah sekian abad lamanya telah mapan. Bahkan, lebih dari itu, kekhawatiran yang mungkin tidak terlalu berlebihan lain adalah hilangnya kelas menengah terdidik dari anak muda NU. Tesis ini didasarkan atas dinamika kehidupan saat ini disertai dengan kompleksitas masalah yang tidak bisa dipecahkan atau dijawab tuntas oleh institusi NU. Sementara, propaganda kelompok Islam radikal intoleran ini diikuti dengan tahapan pengkaderan yang jelas, sistem managemen yang profesional, penguasaan wilayah di daerah pinggiran dengan rintisan bangunan perumahan yang mulai menjamur di berbagi wilayah, penataan keuangan (fundraising) untuk keberlangsungan (sustainabelitas) lembaga secara konkrit.

Pada awal-awal tahun 1990-an, Nurcholis Madjid pernah memprediksikan, bahwa, suatu saat akan terjadi booming kelas menengah terdidik NU. Tesis Nurcholis tersebut dalam kenyataanya benar terjadi. Memasuki tahun akhir tahun 1990-an, dan terlebih lagi mulai awalawal tahun 200-an, "ledakan" anak muda NU dengan back ground pendidikan tinggi terjadi di

\footnotetext{
${ }^{18}$ Ahmad Farid, Pendidikan Berbasis Metode Ahlus Sunnah wal Jama'ah (Surabaya: Pustaka eLBA, 2011).

${ }^{19}$ Masyhudi Muchtar, Aswaja An-Nahdliyah (Surabaya: Khalista, 2007), 81.
} 
mana-mana, begitu pula pendirian Pendidikan Tinggi NU sudah lebih dari 258 se Indonesia. Kalau pada era awal tahun 1980-an hingga 1990-an, sarjana NU hanya berkutat pada disiplin ilmu-ilmu keagamaan, ditambah sedikit sarjana dari disiplin ilmu-ilmu sosial. Namun saat ini, hampir semua disiplin keilmuan telah banyak melahirkan sarjana dari anak-anak NU. Tidak kurang-kurang dijumpai Master, Doktor dan Profesor dari disiplin ilmu-ilmu esakta, fisika, kimia, kedokteran, teknik dan sebagainya. Bahkan, dalam banyak kasus, berbagai jabatan strategis, baik di birokrasi, direktur perusahaan swasta, wirausahawan, pengusaha menengah, dan berbagai jabatan prestisius lainnya juga telah diisi oleh anak-anak dari back ground nahdliyin, dan sekarang telah mulai booming. ${ }^{20}$

Persoalannya tidak berhenti di sini saja, karena tidak serta merta lantas mereka akan berfikir untuk NU, walaupun booming memang benar-benar telah terjadi. Namun, sekali lagi dalam banyak kasus, NU kurang bisa me-manage kader-kader potensial tersebut. Dalam konteks ini, kita belum pernah memiliki sistem atau mekanisme untuk mempersatukan mereka. Kita hanya tahu, kalau Si A adalah Doktor Kimia lulusan AS, Si B adalah manager salah satu perusahaan swasta terkemuka dan seterusnya. Pada proses-proses sebelumnya NU tidak pernah tahu atau tidak pernah mengantarkan si dia hingga akhirnya menjadi seorang Doktor terkenal atau seorang pengusaha sukses. Pemandangan ini berbeda dengan sistem pengkaderan yang dijumpai tradisi kelompok Islam Radikal intoleran. Sebut saja DDII, yang dibidani pendiriannya oleh Muhammad Natsir, memiliki sistem pengkaderan dan distribusi kader yang sangat baik. Setiap bulan secara regular menyelenggarakan berbagai training da'i untuk akhirnya diterjunkan ke seluruh pelosok tanah air sebagai ideolog organisasi. Lesson learned serupa juga ditemui diberbagai organisasi yang selama ini di cap sebagai ormas keagamaan yang mengusung ideologi trans-nasional: Tarbiyah, Salafi, MMI, FPI, JI dan sebagainya. Beberapa organisasi yang disebut terakhir ini memiliki sistem pengkaderan yang sangat teratur. Managemen kelembagaan juga berjalan secara sehat. Bahkan mereka memiliki sistem fundraising yang jelas untuk menopang keuangan bagi keberlangsungan lembaga masing-masing. ${ }^{21}$

Di tengah konstelasi berbagai ragam persoalan dan tarik menarik serta persaingan kepentingan antar ormas keagamaan ini, booming sarjana NU tidak serta merta akan menyelesaikan persoalan di tubuh NU. Sebaliknya, kekawatiran baru justru muncul dengan fenomena hengkangnya kader-kader potensial NU masuk ke dalam organisasi-organisasi non mainstream. Jika diminta memilih, hilangnya massa NU tidak begitu mahal dibanding beralihnya kelas menengah terdidik NU. Ada persoalan-persoalan dibalik piliham-pilihan lain dari kelas menengah terdidik, yakni motif ekonomi, karir-jabatan politik maupun jabatan strategis lain,

${ }^{20}$ Nasir, Pemikiran Kalam (Teologi Islam).

21 A. Jauhar Fuad, "Gerakan Kultural Dan Pemberdayaan: Sebuah Imun Atas Radikalisasi Di Sanggar Sekar Jagad Di Sukoharjo,” Al-Tahrir: Journal of Islamic Thought 18, no. 1 (30 Mei 2018): 1-22, https://doi.org/10.21154/altahrir.v18i1.1171.

Tribakti: Jurnal Pemikiran Keislaman

Volume 32, Nomor 1, Januari 2021 
kepuasan intelektual dan kerja-kerja sosial, dan masih banyak lagi. Motif-motif tersebut lambat laun akan ikut menggerus komitmen ke-NU-annya setelah mereka masuk di ormas keagamaan yang baru. Realitas dari kompleksitas masalah yang dihadapi NU seperti deskripsi pada awalawal kiranya memang patut direnungkan demi survevilitas eksistensi NU di masa mendatang. Sebab, tantangan demi tantangan kelihatannya akan semakin besar, seirama dengan dinamika perkembangan dan tuntutan zaman.

\section{Problem Politik Praktis}

Tidak mudah untuk menjawab berbagai dilema maupun problem yang dihadapi oleh NU di tengah menguatnya kelompok Islam non-mainstream. Tetapi, dari sekian akar masalah, faktor politik praktis kelihatannya menjadi akar persoalan yang paling mendasar, di samping masalahmasalah lain tentunya. Sebagaimana penjelasan singkat pada analisis-analisis sebelumnya, disadari atau tidak, kader NU sepertinya tidak memiliki pilihan lain untuk mendongkrak karir, ekonomi maupun status sosial lain, kecuali melalui jalur politik. Seperti analisis Nakamura, dua pertiga fase sejarah NU, lebih banyak dihabiskan energinya untuk bersentuhan dengan politik praktis, ketimbang berurusan dengan dakwah sosial-keagamaan ataupun mengurus problem konkrit yang dihadapi oleh konstituen NU pada level basis. Akibat kekosongan peran ini, kelompok Islam non-mainstream datang untuk memberi solusi alih-alih mengajak pada ajaran keagamaan baru, yang lebih menjanjikan walaupun adanya perubahan ideologi dan mindset yang kurang familier dalam hati maupun pikiran. ${ }^{22}$

Khittah 1926 telah tercoreng dengan lahirnya PKB pada 1998, siapapun boleh berdebat tentang keterlibatan NU, baik langsung maupun tidak langsung pada konteks PKB ini. Siapapun juga boleh berspekulasi tentang lebih besar mana antara manfaat dan mudlorot dengan hadirnya PKB. Tetapi, kita berkeyakinan, bahwa NU harus benar-benar netral dari berbagai politik yang ada, tidak terkecuali apakah itu PKB, PPP dan lain sebagainya. Pengalaman telah mengajarkan kepada warga NU, bahwa politik telah melahirkan keretakan sosial, memudarkan solidaritas antar warga NU, akibat perbedaan visi dalam memahami sikap politik seorang panutan di atasnya. ${ }^{23}$

Sejarah NU pada 1952, menurut Greg Fearlu, saat NU harus memisahkan diri dari Masyumi dan memilih berdiri sendiri menjadi Partai Politik telah menyeret NU jauh masuk pada wilayah politik praktis dan tanpa lagi mengindahkan garis-garis dakwah perjuangan NU semestinya. ${ }^{24}$ Pengalaman yang hampir serupa juga terjadi pada 1973 hingga 1984. Pada era ini,

${ }^{22}$ Mun'im A. Sirry, Membendung militansi agama: iman dan politik dalam masyarakat modern (Penerbit Erlangga, 2003).

${ }^{23}$ Suaidi Asyari, Nalar Politik NU-Muhammadiyah ; Overcrossing Java Sentris (Yogyakarta: Lkis Pelangi Aksara, 2009); Greg Fealy, Ijtihad Politik Ulama; Sejarah NU 1952-1967 (Yogyakarta: Lkis Pelangi Aksara, 2012).

24 Nico Kaptein, review of Review of Nahdlatul Ulama; Traditional Islam and modernity in Indonesia, oleh Greg Barton dan Greg Fealy, Bijdragen tot de Taal-, Land-en Volkenkunde 154, no. 3 
meskipun NU tidak langsung berpolitik praktis, para kader-kadernya banyak duduk di PPP, bahkan, NU tidak lain adalah unsur resmi di dalam PPP tersebut.

Konstituen dari grass-root NU tidak lagi mendapat pelayanan yang baik. Walaupun banyak kader NU duduk di DPR, manfaat bagi NU, bahkan pada warga NU tidak banyak didapatkan. Yang terjadi malah sebaliknya, pengayaan secara materi maupun karir politik hanya pada pelaku-pelaku politik tersebut. Di berbagai tempat, meskipun perolehan kursi DPRD banyak didominasi oleh partai yang identik dengan NU, namun keberadaan institusi NU juga tidak lebih baik dari pada periode-periode sebelumnya. Tragisnya lagi, nama NU maupun warga NU ditarik kesana kemari diklaim oleh politisi tertentu untuk kepentingan pribadi. Dari semua catatan negatif ini, terdapat suatu hal yang harus dibayar mahal oleh warga NU, yakni memudarnya solidaritas, jiwa keikhlasan, nilai-nilai perjuangan pada diri warga NU. Struktur sosial menjadi rapuh, toleransi antar warga NU menjadi barang mahal. Konflik terjadi dimana-mana, NU yang dahulu terkenal kaya dengan mekanisme penyelesaian konflik, saat ini menjadi susah dilakukan. ${ }^{25}$ Pragmatisme dan atribut-atribut material lainnya menggantikan nilai barakah, keikhlasan dan perjuangan sudah terkubur, dan lupa pada visi dan misi Muassis di saat mendirikan NU pada 1926 itu, yaitu menjadi Jam'iyyah Diniyyah, yang bergerak dalam bidang ekonomi, pendidikan, kesehatan, budaya, dan lain sebagainya. ${ }^{26}$

\section{NU: Universalisme Ajaran \& Moderatisme Islam}

Kehadiran dan kelahiran NU di Indonesia sebagai organisasi para Ulama di tengahtengah masyarakat plural dan majemuk bukanlah suatu kebetulan, tetapi merupakan pilihan logis dan sadar atas terbentuknya NU oleh para Ulama tradisional dalam menjembati berbagai persoalan pada waktu itu. Jika diteliti secara seksama, bahwa kelahiran NU telah dihadapkan pada pertarungan ideologi yang berkembang sebelumnya, tidak hanya ideologi keagamaan yang berkembang di Indonesia, tetapi juga ideologi yang diimpor dari Mesir dan Saudi Arabia. Berbeda dengan Ormas keagamaan lainnya, kehadiran NU merupakan bagian dari desakan lokal untuk merawat tradisi yang berkembang di Indonesia, yang saat terancam oleh kalangan reformis atau medernis. $^{27}$

Ini adalah faktor dari dalam atau internal di tanah air. Tetapi dari sisi eksternal, kehadiran NU langsung atau tidak langsung sebagai bentuk resistensi terhadap faham wahabisme di satu sisi dan menguatnya kelompok pembaharu di Mesir yang dikomandani oleh Jamaluddin Al-Afghani

(1998): 493-95; Greg Barton, "The Gülen Movement, Muhammadiyah and Nahdlatul Ulama: Progressive Islamic Thought, Religious Philanthropy and Civil Society in Turkey and Indonesia," Islam and ChristianMuslim Relations 25, no. 3 (3 Juli 2014): 287-301, https://doi.org/10.1080/09596410.2014.916124.

${ }^{25}$ Achmad Siddiq, Khitthah Nahdliyah (Surabaya: Khalista, 2006).

${ }^{26}$ Nitra Galih Imansari, Peran Ulama NU dalam Menangkal Radikalisme di Jawa Timur (Surabaya: Tesis Program Pascasarjana Universitas Islam Negeri Sunan Ampel Surabaya, 2019), 81.

${ }^{27}$ Choirul Anam, Pertumbuhan dan Perkembangan Nahdlatul Ulama (Surakarta: Jatayu, 1985), 28.

Tribakti: Jurnal Pemikiran Keislaman

Volume 32, Nomor 1, Januari 2021 
dan Rasyid Ridho. Wahabi di Hijaz secara puritan hendak mengikis habis Madzhab Syafi'i dan berbagai simbol tradisi di kalangan Ahlussunnah wa al-Jama'ah dari aspek praktek ajaran tasawuf. Sebagaimana diketahui, sebagai bagian dari proyek wahabisme di antaranya adalah hendak melarang kebebasan bermadzhab dan memugar makam Nabi Muhammad dan berbagai situs keagamaan lain yang oleh wahabi dianggap bagian dari bid'ah. Rencana ini ditentang oleh NU dengan mengirimkan delegasi para Ulama menghadap ke Raja Sa'ud di Saudi Arabia yang terkenal dengan Komite Hijaz. ${ }^{28}$

Lokalitas itulah yang menjadikan NU sebagai organisasi yang unik. Meskipun NU memiliki cabang-cabang yang tersebar di berbagai negara, namun anggotanya adalah orang-orang Indonesia yang tetap memiliki karakter ke-Indonesiaan. Karakter ke-Indonesiaan ini tidak serta melebur meskipun di negara-negara lain mereka juga bersentuhan dengan ragam ideologi Islam lainnya yang disebut sebagai ideologi trans-nasional. Realitas ini yang membedakan NU dengan organisasi-organisasi lain yang disebut sebagai trans-nasional seperti Wahabi, Salafi, Ihwanul Muslimin (IM), Front Pembela Islam (FPI), atau Jema'ati el-Islami (JI) yang menginternasional. ${ }^{29}$ Meskipun NU memiliki keunikan tersendiri sebagai bagian dari gerakan Islam lokal, NU juga memiliki ajaran-ajaran yang bisa dipertemukan dengan kelompok-kelompok lain di ranah internasional. Ini terlihat dari "cara beragama" ala NU tidak hanya dijumpai di Indonesia, tapi juga di negara-negara lain. Meskipun secara formal organisatoris, mereka bukan kalangan yang bisa dikatakan beragama NU.

Memang harus diakui, bahwa NU bukan sebuah realitas yang tunggal dan monolitik. Sejak awal mula hingga saat ini, para Ulama NU juga memiliki keterkaitan secara historis dengan tradisi intelektual, terutama yang berporos di Mekkah. Namun, berbagai pengalaman di Mekkah selalu dapat didialogkan dengan realitas budaya lokal, meskipun tidak ada jaminan satu suara secara utuh dari para Ulama NU dalam menyikapi persoalan-persoalan keagamaan. Masalah Khilafah Islamiyah misalnya, di antara Ulama NU terkadang juga terjadi perbedaan pendapat. Namun demikian, berbagai perbedaan pendapat ini dapat disatukan oleh prinsip-prinsip fundamental yang tertuang dalam doktrin Ahlussunnah wal al-Jama'ah (Aswaja) NU, yang dirumuskan dalam khittah an-Nahdliyah. Khittah NU, sebagaimana dalam teks Khittah NU hasil Muktamar ke 27 di Situbondo, tidak lain adalah landasan berpikir, bersikap, dan bertindak warga NU. ${ }^{30}$

Secara mendasar, khittah NU memuat beberapa aspek mendasar yaitu : (1) Dasar-dasar faham keagamaan, (2) Konsepsi hubungan horizontal atau sikap kemasyarakatan, (3) Perilaku yang terbentuk dari faham keagamaan dan kemasyarakatan, dan (4) Konsepsi politik kenegaraan. Berbeda dengan berbagai ragam Ormas Islam Radikal, NU mendasarkan faham keagamaan pada

\footnotetext{
${ }^{28}$ Abdusshomad, Hujjah NU, 25.

${ }^{29}$ Alarna, NU, Kritisisme dan Pergeseran Makna Aswaja, 69.

${ }^{30}$ Siddiq, Khitthah Nahdliyah.
} 
3 (tiga) pilar : Kalam (teologi), Fiqh, dan tasawuf. Dari aspek fundamental doktrinal saja telah dapat diketahui, bahwa dalam tradisi keagamaan NU, lebih mencerminkan nuansa egalitar, plural, fleksibel dan tidak monolitik. Penerimaan NU terhadap ragam khazanah keilmuan Islam klasik sebagai panduan kehidupan sosial-politik-kemasyarakatan cukup menjadi penanda oleh warga NU. Jika NU memegang 3 (tiga) dasar ajaran fundamental tersebut. Bagi kalangan Islam radikal intoleran, ajaran tasawuf, teologi dan tradisi bermadzhab dianggap sumber bagi munculnya bid'ah, khurafat dan tahayul. Sebagai gantinya, mereka cukup mendasarkan keagamaan hanya merujuk pada Al-Qur'an, Hadits dan anjuran untuk melakukan ijtihad secara mandiri. ${ }^{31}$

Sementara, dalam penjabaran khittah NU, yang dimaksud dengan konsepsi hubungan horizontal atau sikap kemasyarakatan bertumpu pada prinsip-prinsip : (1) tawassut dan I'tidal (sikap tengah atau moderat dan adil), (2) tasammuh (toleran), (3) tawazun (sikap seimbang), dan (4) amal ma'ruf nahi munkar. Prinsip-prinsip keagamaan ini, dalam implementasinya diakui dapat membentuk watak dan perilaku warga NU yang moderat, fleksibel, toleran dan dapat menghargai keragaman, pluralitas, dan kemajemukan suku, etnis, budaya dan seterusnya yang dijumpai dalam tatanan sosial masyarakat Indonesia maupun tatanan global. ${ }^{32}$ Realitas ini pula, yang menempatkan ajaran NU mampu menyerap berbagai ragam tradisi lokal yang positif serta perubahan secara fleksibel tanpa harus terjadi resistensi secara radikal. Akhirnya, atas dasar tiga pilar tadi, NU mampu merumuskan konsep hubungan antara agama (Islam) dan politik (negara) tanpa harus kaku, rigit, dan hitam putih harus secara formal berdasarkan syariah Islam. Syariah Islam, bagi NU tidak harus diformalisasikan secara verbal. Sebaliknya, yang penting bagi NU adalah syariah Islam cukup menjadi spirit kehidupan masyarakat Indonesia yang memang majemuk dan plural.

\section{NU di Tengah Tradisi Masyarakat Global}

Dewasa ini, belum terdapat literatur yang memadai untuk dapat dijadikan bahan rujukan sebagai dasar pijakan menilai sikap atau gerakan NU dalam menghadapi dunia globalisasi. Istilah globalisasi belakangan ini digunakan sebagai ciri untuk menandai kemajuan modernitas yang semakin cepat, semakin radikal dan semakin kuat. Dunia Barat yang memegang kendali supremasi di bidang kemajuan ilmu pengetahuan dan teknologi merupakan pusat dominan penyebaran proses globalisasi, Giddens mengartikan globalisasi sebagai perkembangan pesat di

31 Halimar Rasyid, Ahmad Solikin, Moh. Sa'diyin, Intoleransi, Radikalisme, dan Teroris di Lamongan (Jakarta: Jurnal Polinter Prodi Ilmu Politik FISIP UTA ’45 Vol 4, No 1, Maret-Agustus 2018), 17.

${ }^{32}$ Alarna, NU, Kritisisme dan Pergeseran Makna Aswaja; A. Jauhar Fuad, "Akar Sejarah Moderasi Islam Pada Nahdlatul Ulama," Tribakti: Jurnal Pemikiran Keislaman 31, no. 1 (13 Januari 2020): 153-68, https://doi.org/10.33367/tribakti.v31i1.991.

Tribakti: Jurnal Pemikiran Keislaman

Volume 32, Nomor 1, Januari 2021 
bidang komunikasi, transportasi dan teknologi informasi yang dapat menghadirkan sebagian besar wilayah di dunia jauh meskipun budaya yang mereka miliki mudah dijangkau. ${ }^{33}$

NU sebagai organisasi kemasyarakatan, telah menjadi bagian integral dari komunitas Muslim Indonesia yang terus memelihara dan melestarikan bangunan tradisi dan akar budaya tradisionalnya, meskipun tidak harus mengisolasi dan menutup diri untuk menerima hal-hal positif dari derasnya budaya Barat atau komunitas global lainnya. Begitu pula NU tetap konsisten dalam menerapkan strategi kebudayaan karena namanya telah dirumuskan dengan tepat dalam kaidah "al-Muhafadzah 'ala al-qadimi as-Shalih wa al - akdzu bi al-jadidi al-ashlah" (memelihara tradisi lama yang baik, dan mengambil tradisi baru yang lebih baik). ${ }^{34}$

Prinsip dan strategi budaya yang diadaptasi di atas berimplikasi pada hasil budaya Barat yang positif seperti sains dan teknologi yang tidak terbantahkan, NU dan seluruh jajaran jamaah dan warganya menghargai, mempelajari, menerima, dan menerapkan dalam kehidupan nyata, karena ini instrumen untuk membangun budaya dan peradaban, demi kelangsungan kehidupan manusia yang senantiasa memberi manfaat pada lingkungan sekitarnya, bahkan untuk diwariskan pada generasi penerus. Penerimaan NU terhadap hasil budaya Barat yang positif sangat dibutuhkan, sebagai injeksi membangun semangat baru, dan kebutuhan untuk memodernisasi khidmat NU bagi masyarakat di tengah persaingan global.

Untuk membawa diri di era globalisasi, NU tidak ada pilihan lain selain menjadikan dirinya Jam'iyyah Diniyyah-sosial modern yang terbuka, tanpa kehilangan ideologi dan nilai-nilai dasar tradisionalnya, secara kreatif meramu tradisi dan modernisasi serta menyelaraskan keduanya dalam satu tatanan bangunan yang serasi dan ideal, sehingga tidak kalah pentingnya hanya menunjukkan sisi tradisionalismenya, tetapi menunjukkan sebagai Jam'iyyah Diniyah yang mampu beradaptasi dengan dunia global. Citra modernitas tercermin pada kelompok nahdliyin dengan melakukan rekonstruksi mental agar memiliki sikap mental masyarakat modern. Inkeles, sosiolog dari University of Havard, Amerika Serikat, mengatakan bahwa manusia modern adalah; (a) siap mendapatkan pengalaman baru dan terbuka terhadap pembaruan dan perubahan (inovasi dan perubahan), (b) mampu membentuk isu-isu besar yang muncul, dan menjadi sikap dan pilihan masyarakat, (c) orientasi mereka terhadap berbagai opini yang ada lebih transparan dan demokratis. ${ }^{35}$ Artinya dia lebih sadar akan berbagai sikap dan pendapat di sekitar dirinya, tidak menutup diri, tidak serta merta menerima gagasan atasannya dalam hierarki kekuasaan, juga tidak begitu saja menolak pendapat orang yang posisinya berada di bawahnya, dus lebih akomodatif terhadap masukan, yang tidak membeda-bedakan satu sama lain, (d) berorientasi pada masa kini

${ }^{33}$ Alarna, NU, Kritisisme dan Pergeseran Makna Aswaja, 88.

34 Tholhah Hasan, Ahlussunnah Wal Jama'ah in The Perception and Tradition of NU (Jakarta: Nirmana Media, 2018), 88.

35 Arif Rifkiawan Hamzah, Radikalisme dan Toleransi Berbasis Islam Nusantara (Yogyakarta: Pascasarjana Universitas Islam Sunan Kalijogo, Jurnal Sosiologi Reflexi Volume 13, No 1, Oktober 2018), 25. 
dan masa depan, tetapi juga tidak mengabaikan masa lalu, artinya berpikir secara komprehenshif, (e) terlibat dalam perencanaan dan pengorganisasian serta berkeyakinan sama sebagai cara menata kehidupannya, sehingga terjadi harmonisasi, (f) meyakini bahwa manusia dapat belajar ke tingkat yang jauh dari mendominasi lingkungannya, untuk memajukan tujuan dan sasarannya dan bukan sebaliknya, (g) memiliki keyakinan bahwa dunia dapat diandalkan, dan bahwa orang lain dan lembaga-lembaga di sekitarnya dapat diandalkan untuk memenuhi kewajiban dan tanggung jawabnya. Ia tidak percaya bahwa segala sesuatu ditentukan oleh takdir atau oleh tingkah laku khusus dari sifat dan karakteristik manusia saja, (h) sadar akan martabat orang lain dan cenderung menunjukkan rasa hormat kepada mereka, dan saling menghormati dan menghargai, (i) percaya pada sains dan teknologi, sebagai tangga untuk membangun budaya dan peradaban manusia, (j) percaya pada keadilan yang terbagi. Artinya, pahala harus sesuai dengan kontribusi dan bukan berdasarkan perbuatan atau sifat khusus orang yang tidak ada hubungannya dengan kontribusi. ${ }^{36}$

Ciri-ciri manusia modern seperti yang diungkapkan oleh Inkeles di atas diangkat dari pengamatan terhadap paradigma kehidupan Barat yang berpandangan kehidupan sekuler dan antroposentris. Meskipun demikian, sifat-sifat tersebut dapat dianjurkan untuk dibudidayakan dalam diri umat Islam pada umumnya, dan pada pribadi nahdiyin pada khususnya, dengan syarat tumbuhnya sifat-sifat tersebut berdasarkan nilai-nilai dan motivasi Islam sehingga tingkah laku dan tujuan hidup yang ingin dicapai tetap tercapai. mengandalkan mencari dan memperoleh ridha Allah SWT. Dalam perspektif Islam Ahlussunnah wa al-Jama'ah bahwa Allah berada dibalik dinamika kehidupan manusia dari waktu ke waktu, sehingga keberlangsungan dan dinamika kehidupan manusia itu ada intervensi dari Allah, tidak berlangsung dengan sendirinya, namun manusia tetap harus berikhtiar, kemudian disertai doa dan tawakkal kepada Allah SWT.

\section{Kesimpulan}

Islam agama rahmatan lil'alamien, ketika umatnya memahami Islam memiliki sudut pandang yang berbeda satu dengan yang lain karena latar belakang pendidikan, kualitas pemahaman, kehidupan, dan letak geografis, sehingga terjadi timbulnya berbagai paham dan aliran. Di Indonesia secara umum ada kelompok Islam moderat yang biasa disebut mainstream yang selama ini banyak mewarnai bangsa Indonesia, mulai dari sebelum merdeka, menghadapi penjajah hingga merdeka, orde lama dan orde baru, dan di era reformasi tetap menunjukkan perannya walaupun mendapat ujian di tengah maraknya wajah faham Islam fundamental (radikal intoleran) yang kini banyak menampakkan kegarangannya dalam menyikapi berbagai persoalan di Indonesia dengan turun jalan dan pengerahan masa besar-besaran yang disebut dengan kelompok non mainstream, bahkan kelompok yang kedua ini mulai masuk ke gelanggang politik

${ }^{36}$ Nasir, Pemikiran Kalam (Teologi Islam).

Tribakti: Jurnal Pemikiran Keislaman

Volume 32, Nomor 1, Januari 2021 
nasional, sisi lain kelompok Islam mainstream tidak berpolitik praktis, tetapi lebih menekankan pada pengembangan umat karena jam 'iyyah diniyah.

Lahirnya kelompok terdidik NU, akhir-akhir ini memberi angin segar bagi kebangkitan kelompok mainstream baik dalam bidang ekonomi, sosial politik, budaya, kesehatan, lingkungan, teknologi informasi, agama dan lain sebagainya, namun kelompok terdidik NU ini bermunculan bukan atas nama NU, tetapi muncul dan berkembang secara alami sehingga bila menempati tempat-tempat strategis dalam pemerintahan, politik, pengusaha suskses, teknokrat, budayawan, agamawan dan seterusnya bukan atas nama NU, tetapi lebih pada profesionalitas dan belum berfikir keras untuk membawa misi NU, karena belum terkonsolidasikan dengan baik. Tragisnya juga terdapat sekolompok Islam mainstream yang potensial menyeberang ke non mainstream, ini tidak lepas kemampuan kelompok mainstream untuk meyakinkannya.

NU memiliki konsep dalam hubungan horizontal atau sikap kemasyarakatan berpegang pada prinsip : (1) tawassut dan I'tidal, (2) tasammuh, (3) tawazun, dan (4) amal ma'ruf nahi munkar. Prinsip keagamaan ini, dalam implementasinya dapat menbentuk watak dan perilaku warga NU yang moderat, fleksibel, toleran dan dapat menghargai keragaman, pluralitas, dan kemajemukan suku, etnis, budaya dan seterusnya dalam tatanan sosial masyarakat Indonesia maupun tatanan global, sehingga NU mampu beradaptasi dengan lingkungan dan tuntutan global.

\section{Daftar Pustaka}

Abdusshomad, Muhyiddin. Hujjah NU. Surabaya: Khalista, 2008.

Alarna, Badrun. NU, Kritisisme dan Pergeseran Makna Aswaja. Yogyakarta: Tiara Wacana, 2000 .

Anam, Choirul. Pertumbuhan dan Perkembangan Nahdlatul Ulama. Surakarta: Jatayu, 1985.

Arif Rifkiawan Hamzah, Radikalisme dan Toleransi Berbasis Islam Nusantara, Yogyakarta: Pascasarjana Universitas Islam Sunan Kalijogo, Jurnal Sosiologi Reflexi Volume 13, No 1, Oktober 2018.

Asyari, Suaidi. Nalar Politik NU-Muhammadiyah ; Overcrossing Java Sentris. Yogyakarta: Lkis Pelangi Aksara, 2009.

Barton, Greg. "The Gülen Movement, Muhammadiyah and Nahdlatul Ulama: Progressive Islamic Thought, Religious Philanthropy and Civil Society in Turkey and Indonesia." Islam and Christian-Muslim Relations 25, no. 3 (3 Juli 2014): 287-301. https://doi.org/10.1080/09596410.2014.916124.

Endang Supriadi, Ghufron Ajib, Sugiarso, Intoleransi dan Radikalisme Agama; Konstruk LSM tentang Program Deradikalisasi. Semarang: JSW/Jurnal Sosiologi Walisongo Vol 4, No 1, 2020. 
Farid, Ahmad. Pendidikan Berbasis Metode Ahlus Sunnah wal Jama'ah. Surabaya: Pustaka eLBA, 2011.

Fealy, Greg. Ijtihad Politik Ulama; Sejarah NU 1952-1967. Yogyakarta: Lkis Pelangi Aksara, 2012.

Fuad, A. Jauhar. "Akar Sejarah Moderasi Islam Pada Nahdlatul Ulama." Tribakti: Jurnal Pemikiran Keislaman 31, no. 1 (13 Januari 2020): 153-68. https://doi.org/10.33367/tribakti.v31i1.991.

. "Gerakan Kultural Dan Pemberdayaan: Sebuah Imun Atas Radikalisasi Di Sanggar Sekar Jagad Di Sukoharjo.” Al-Tahrir: Journal of Islamic Thought 18, no. 1 (30 Mei 2018): 122. https://doi.org/10.21154/altahrir.v18i1.1171.

Hasan, Tholhah. Ahlussunnah Wal Jama'ah in The Perception and Tradition of NU. Jakarta: Nirmana Media, 2018.

Hasan, Tholhah dkk, Radikalisme dalam Persepktif Budaya . Jakarta; Lantabora, 2017.

Halimar Rasyid, Ahmad Solikin, Moh. Sa'diyin, Intoleransi, Radikalisme, dan Teroris di Lamongan, Jakarta: Jurnal Polinter Prodi Ilmu Politik FISIP UTA '45 Vol 4, No 1, Maret-Agustus 2018.

Ismail, Faisal. NU, Moderatisme, dan Pluralisme: Konstelasi Dinamis Keagamaan,

Kemasyarakatan, dan Kebangsaan. IRCISOD, 2020.

Kaptein, Nico. Review of Review of Nahdlatul Ulama; Traditional Islam and modernity in Indonesia, oleh Greg Barton dan Greg Fealy. Bijdragen tot de Taal-, Land- en Volkenkunde 154, no. 3 (1998): 493-95.

Lexy J. Moleong, Metode Penelitian Kualitatif. Jakarta: Grafindo, 2002.

Maskuri Bakri, Metode Penelitian Kualitatif; Teori dan Praktek. Jakarta: Nirmana Press, 2014.

Maskuri Bakri, Radikalisme dan Intoleran dalam Perspektif Bhinneka Tunggal Ika, Malang: Lembaga Penelitian dan Pengabdian pada Masyarakat Universitas Islam Malang, 2020.

Misrawi, Zuhairi. Hadratussyaikh Hasyim Asy'ari: moderasi, keumatan, dan kebangsaan. Penerbit Buku Kompas, 2010.

Muchtar, Masyhudi. Aswaja An-Nahdliyah. Surabaya: Khalista, 2007.

Nasir, Sahilun A. Pemikiran Kalam (Teologi Islam): sejarah, ajaran ,dan perkembangannya. Jakarta: Rajawali Press, $2010 . \quad$ //senayan.iainpalangkaraya.ac.id/index.php?p=show_detail\&id=6224.

Nitra Galih Imansari, Peran Ulama NU dalam Menangkal Radikalisme di Jawa Timur. Surabaya: Tesis Program Pascasarjana Universitas Islam Negeri Sunan Ampel Surabaya, 2019.

Tribakti: Jurnal Pemikiran Keislaman

Volume 32, Nomor 1, Januari 2021 
Proceeding International Seminar on Islamic Civilization. Developing Role of Islamic Education on Multicultural Life and Religious De-Radicalization. Post Graduate Program Qur'anic Sciences University Central Java in Wonosobo in Cooperation with Agency, Development, Education and Training (Balitbang Diklat) Ministry of Religious Affairs Republic of Indonesia, 2019.

Proceedings Islamic International Conference (IIC). The Elements of Multicultural Curriculum in Aspect of Evaluating Curriculum (The Concepts, Nature, and Evaluation Models. Post Graduate Islamic University of Islam Malang, 2018

Ridwan, Abdul Qodir. Gerbang Pesantren, Pengantar Memahami Ajaran Ahlussunnah wal Jama'ah. Kediri: Litbang Lembaga Ittihadul Muballigin PP. Lirboyo, 2010.

Siddiq, Achmad. Khitthah Nahdliyah. Surabaya: Khalista, 2006.

Sirry, Mun'im A. Membendung militansi agama: iman dan politik dalam masyarakat modern. Penerbit Erlangga, 2003. 